\title{
Perjanjian Baku dan Perlindungan Konsumen dalam Transaksi Bisnis Sektor Jasa Keuangan: Penerapan dan Implementasinya di Indonesia
}

\author{
Agus Satory*
}

\begin{abstract}
Abstrak
Ketika konsumen tertarik dengan promosi yang ditawarkan pelaku usaha jasa keuangan, sesungguhnya ia tidak menyadari persoalan yang akan dihadapi berikutnya. Persoalan akan timbul ketika konsumen menghadapi formula perjanjian baku yang di dalamnya banyak terdapat klausula baku yang mengharuskan konsumen setuju. Pada praktiknya, saat ini tidak ada jasa keuangan yang tidak menggunakan format perjanjian dan klausula baku dalam bertransaksi dengan para konsumen. Bentuk perjanjian semacam ini jelas memposisikan konsumen sebagai pihak yang tidak punya daya tawar, sehingga apapun isi dari perjanjian baku tersebut mau tidak mau harus disetujui, meskipun pada dasarnya konsumen mengetahui bahwa isi perjanjian memberatkan dirinya. Dalam wacana perlindungan konsumen, hal ini dikenal sebagai prinsip take it or leave it. Penggunaan perjanjian baku dengan sendirinya membuka peluang bagi penyedia jasa keuangan untuk memasukkan semua klausula yang menguntungkan dirinya. Biasanya, konsumen yang berhubungan dengan jasa keuangan akan menjumpai berbagai kewajibannya sudah tertuang dalam perjanjian tanpa dapat dinegosiasikan. Kewajiban tersebut diantaranya mengenai biaya yang harus ditanggungnya, suku bunga, pemberian kuasa sepihak, serta semua kewajiban yang akan timbul di kemudian hari. Praktis sangat sedikit hak konsumen dituangkan dalam perjanjian baku ini.
\end{abstract}

Kata kunci: perjanjian baku, perlindungan konsumen, jasa keuangan, pelaku usaha jasa keuangan, posisi tawar.

\section{Standard Contract and Consumer Protection on Business Transaction of Financial Sector: Indonesia's Practice and Implementation}

\begin{abstract}
Consumers are usually unaware of issue might arise when they were interested on the financial services entity offer. The issue might arise when consumers given a standard contract formulas that loaded with standard clauses, which been prepared for the consumers to be approved. These days, there is none of financial services entity that do not use a standard contract format which contained standard clauses in their contract with customers. The form of standard contract is obviously set the consumer to lose their bargain
\end{abstract}

PADJADJARAN Jurnal IImu Hukum Volume 2 Nomor 2 Tahun 2015 [ISSN 2460-1543] [e-ISSN 2442-9325]

* Dosen Tetap dan Ketua Program Konsentrasi Hukum Ekonomi dan Bisnis Fakultas Hukum Universitas Pakuan, J. Pakuan PO BOX 452 Kota Bogor, gusto adini@yahoo.com, S.H., M.H. (Universitas Pakuan). 
power. It makes the consumers do not have any choice beside consent even if they know that the contract is harmful for them. In the discourse of consumer protection, this mechanism is known as the principle of "take it or leave it". The use of a standard contract by itself open an opportunity for financial service providers to include all the clauses that benefit him. Usually consumer-related financial services will find a variety of obligations stated in the contract can be negotiated without. Example of costs that must be borne, interest rates, giving unilateral power, and all the obligations that will arise in the future. Practically very little consumer rights set forth in this standard contract.

Keywords: standard contract, consumers protection, financial services, financial services business actors, bargaining position.

\section{A. Pendahuluan}

Pertumbuhan aktivitas ekonomi masyarakat di berbagai bidang telah mendorong tumbuhnya sektor jasa keuangan yang begitu pesat. Pertumbuhan ini dapat dilihat baik dari segi kuantitas pelaku usaha maupun jenis layanan yang ditawarkan, seperti layanan jasa perbankan, jasa asuransi, jasa pembiayaan konsumen, dan berbagai jenis layanan jasa keuangan lain seperti jual beli valuta asing, penukaran uang, dan lain-lain. Regulasi dan kebijakan pemerintah di bidang jasa keuangan juga berjalan dinamis seiring perubahan dan perkembangan yang ada di masyarakat, bahkan cenderung mempermudah pertumbuhannya. Kondisi tersebut pada satu pihak sangat bermanfaat bagi kepentingan konsumen, karena kebutuhan yang diinginkan dapat terpenuhi serta semakin terbuka lebar kebebasan untuk memilih aneka jenis kualitas sektor jasa keuangan yang ditawarkan.

Di sisi lain, kondisi dan fenomena tersebut dapat mengakibatkan kedudukan Pelaku Usaha Jasa Keuangan (PUJK) dan konsumen menjadi tidak seimbang. ${ }^{1}$ Konsumen hanya dijadikan obyek aktivitas bisnis dari PUJK untuk meraup keuntungan sebesar-besarnya melalui kiat iklan, promosi, cara penjualan, serta penerapan perjanjian baku yang merugikan konsumen. Kesadaran konsumen yang rendah akan hak dan kewajibannya, serta kurangnya pendidikan konsumen, menjadi titik masuk dari perangkap yang ditebarkan PUJK.

Dalam situasi dan kondisi tersebut dapat diketahui bahwa penggunaan perjanjian baku dalam transaksi bisnis dapat menimbulkan ketidak seimbangan

\footnotetext{
1 Konsumen dalam konteks ini adalah pihak-pihak yang menempatkan dananya dan/atau memanfaatkan pelayanan yang tersedia di lembaga jasa keuangan antara lain nasabah pada perbankan, pemodal di pasar modal, pemegang polis pada perasuransian, dan peserta pada dana pensiun, berdasarkan peraturan perundangundangan di sektor jasa keuangan, sedangkan yang dimaksud dengan PUJK adalah bank umum, bank perkreditan rakyat, perusahaan efek, penasihat investasi, bank kustodian, dana pensiun, perusahaan asuransi, perusahaan reasuransi, lembaga pembiayaan, perusahaan gadai, dan perusahaan penjaminan, baik yang melaksanakan kegiatan usahanya secara konvensional maupun secara syariah.
} 
antara PUJK dan konsumen, sehingga diperlukan landasan hukum yang kuat bagi pemerintah dan masyarakat untuk melakukan upaya perlindungan dan pemberdayaan konsumen melalui pembinaan dan pendidikan konsumen. Upaya ini penting untuk mengimbangi kegiatan PUJK yang menjalankan prinsip ekonomi untuk mendapatkan keuntungan semaksimal mungkin dengan modal seminimal mungkin. Prinsip ekonomi tersebut dapat merugikan kepentingan konsumen, baik secara langsung maupun tidak langsung.

Sistem perekonomian yang semakin kompleks berdampak pada perubahan konstruksi hukum dalam hubungan antara produsen dan konsumen. Perubahan konstruksi hukum diawali dengan perubahan paradigma hubungan antara konsumen dan produsen. Hubungan yang semula dibangun atas prinsip caveat emptor (yang menekankan keharusan konsumen berhati-hati dalam melakukan transaksi dengan produsen), berubah menjadi prinsip caveat venditor (yang menekankan pada kesadaran produsen untuk melindungi konsumen). ${ }^{2}$

Konstruksi hubungan hukum antara PUJK dengan konsumen semestinya setara (equal), namun secara de facto maupun de jure konsumen ada dalam posisi yang lemah di hadapan penyedia jasa. Terdapat banyak faktor yang menyebabkan lemahnya posisi konsumen, antara lain adalah faktor ketidaktahuan konsumen atau kurangnya informasi dan ketiadaan daya tawar konsumen, serta posisi konsumen yang seolah-olah berada satu langkah di belakang pelaku usaha. Di sisi lain, PUJK tampak lebih well in formed dan powerful di hadapan konsumennya. Dapat dikatakan bahwa seluruh rangkaian dari produk layanan jasa keuangan dipahami dengan baik oleh penyedia jasa, namun tidak bagi konsumen. Dengan demikian, ketidakseimbangan kedudukan hubungan hukum antara konsumen dan PUJK dibangun itulah yang seringkali menimbulkan berbagai macam kerugian bagi konsumen.

Berdasarkan kondisi tersebut diperlukan upaya pemberdayaan konsumen melalui pembentukan undang-undang yang dapat melindungi kepentingan konsumen secara integratif dan komprehensif serta dapat diterapkan secara efektif di masyarakat. Peranti hukum tidak dimaksudkan untuk mematikan usaha para pelaku usaha, tetapi justru untuk mendorong iklim berusaha yang sehat dan melahirkan perusahaan-perusahaan yang tangguh dalam menghadapi persaingan melalui pelayanan dan penyediaan barang dan/atau jasa yang berkualitas. Sikap keberpihakan kepada konsumen itu juga dimaksudkan sebagai wujud kepedulian yang tinggi terhadap konsumen (wise consumerism). ${ }^{3}$

2 Inosentius Samsul, Perlindungan Konsumen: Kemungkinan Penerapan Tanggung Jawab Mutlak, Jakarta: Pascasarjana FHUI, 2004, hlm. 4.

3 Yusuf Shofie dan Somi Awan, Sosok Peradilan Konsumen: Mengungkap Pelbagai Persoalan Mendasar BPSK, Jakarta: Piramedia, 2004, hlm. 14. 
Pada tanggal 20 April 1999 diundangkan Undang-Undang Nomor 8 Tahun 1999 tentang Perlindungan Konsumen (UU PK) yang mulai berlaku 20 April 2000. Tujuan utama undang-undang ini antara lain untuk meningkatkan harkat dan martabat konsumen dengan cara menghindarkannya dari akses negatif pemakaian barang dan/atau jasa; serta menumbuhkan kesadaran pelaku usaha mengenai pentingnya perlindungan konsumen, sehingga tumbuh sikap yang jujur dan bertanggung jawab dalam berusaha. Undang-undang ini diharapkan dapat berlaku efektif melindungi 250 juta penduduk Indonesia yang notabene adalah konsumen.

Kemudian, selain terbitnya UU PK sebagai umbrella act dalam perlindungan konsumen, hukum perlindungan konsumen di Indonesia, sektor jasa keuangan mengalami perkembangan signifikan pascaterbitnya Undang-Undang Nomor 21 Tahun 2011 tentang Otoritas Jasa Keuangan (OJK). Komitmen perlindungan konsumen sektor jasa keuangan telah diimplementasikan di Indonesia, di bawah pengawasan OJK. Dalam upaya pemberdayaan konsumen sektor jasa keuangan melalui perlindungan konsumen dan peningkatan akses keuangan ke masyarakat, pada tahun 2013 OJK telah menerbitkan Peraturan OJK Nomor 01/POJK.07/2013 tentang Perlindungan Konsumen Sektor Jasa Keuangan. Sebagai peraturan pelaksananya, diterbitkanlah 5 Surat Edaran OJK, yaitu:

1. Surat Edaran OJK Nomor 1/SEOJK.07/2014 tentang Pelaksanaan Edukasi Dalam Rangka Meningkatkan Literasi Keuangan Kepada Konsumen dan/atau Masyarakat;

2. Surat Edaran OJK Nomor 2/SEOJK.07/2014 tentang Pelayanan dan Penyelesaian Pengaduan Konsumen pada Pelaku Usaha Jasa Keuangan;

3. Surat Edaran OJK Nomor 12/SEOJK.07/2014 tentang Penyampaian Informasi Dalam Rangka Pemasaran Produk dan/atau Layanan Jasa Keuangan;

4. Surat Edaran OJK Nomor 13/SEOJK.07/2014 tentang Perjanjian Baku;

5. Surat Edaran OJK Nomor 14/SEOJK.07/2014 tentang Kerahasiaan dan Keamanan Data dan/atau Informasi Pribadi Konsumen.

Selain itu pada tahun 2014 OJK juga telah menerbitkan Peraturan OJK Nomor 1/POJK.07/2014 tentang Lembaga Alternatif Penyelesaian Sengketa (LAPS) di Sektor Jasa Keuangan.

Dewasa ini terdapat banyak perangkat hukum yang tidak applicable atau tidak efektif dalam penerapannya. Selanjutnya, terdapat aturan hukum yang unik karena tidak pernah atau jarang sekali diterapkan. Permasalahan ini merupakan bagian dari manajemen pembangunan hukum di Indonesia. ${ }^{4}$ Termasuk permasalahan perangkat hukum yang belum dapat diterapkan sesuai dengan tujuannya tersebut

4 Abdul Halim Barkatulah, Hukum Perlindungan Konsumen: Kajian Teoretis dan Perkembangan Pemikiran, Bandung: Nusa Media, 2008, hlm. 183. 
adalah UUPK, Peraturan OJK Nomor 01/POJK.07/2013, serta Surat Edaran OJK Nomor 13/SEOJK.07/2014 yang mengatur mengenai perjanjian baku. Dalam penerapannya terjadi ketidakseimbangan dan menimbulkan kerugian bagi konsumen yang terlibat dalam proses transaksi bisnis sektor jasa keuangan, terutama ketika konsumen dihadapkan pada kebutuhan untuk memanfaatkan jasa yang ditawarkan oleh PUJK.

Banyak kasus atau gugatan yang masuk ke Badan Penyelesaian Sengketa Konsumen (BPSK) terkait dengan tranksaksi bisnis sektor jasa keuangan. Berdasarkan pengalaman penulis sebagai Anggota BPSK Kota Bogor, kasus yang sering masuk untuk diperiksa dan ditangani dalam sengketa konsumen adalah pada sektor jasa keuangan. Sebagai contoh perjanjian baku yang diterapkan oleh perusahaan pembiayaan (leasing) masih menggunakan klausula baku yang merugikan konsumen, yang menyatakan pemberian kuasa dari konsumen kepada PUJK, baik secara langsung maupun tidak langsung, untuk melakukan segala tindakan sepihak atas barang yang diagunkan oleh konsumen. Salah satu contohnya misalkan tindakan penarikan kendaraan secara sepihak dan pelaksanaan eksekusi terhadap benda yang menjadi obyek jaminan fidusia tanpa persetujuan dari konsumen.

\section{B. Pengertian Perjanjian Baku}

Definisi perjanjian secara umum diberikan dalam Pasal 1313 KUHPerdata yaitu suatu perbuatan dengan mana satu orang atau lebih mengikatkan dirinya terhadap satu orang lain atau lebih. R. Subekti menyatakan bahwa suatu perjanjian adalah suatu peristiwa dimana seseorang berjanji kepada orang lain atau di mana dua orang itu saling berjanji untuk melaksanakan sesuatu. Dari peristiwa ini timbul hubungan perikatan. ${ }^{5}$

Menurut Abdulkadir Muhammad, perjanjian adalah suatu persetujuan dengan mana dua orang atau lebih saling mengikatkan diri untuk melakukan suatu hal dalam lapangan harta kekayaan. ${ }^{6}$ Sudikno Mertokusumo berpendapat bahwa perjanjian adalah hubungan hukum antara dua pihak atau lebih berdasarkan kata sepakat untuk menimbulkan suatu akibat hukum. Dengan demikian, kedua belah pihak sepakat untuk menentukan peraturan atau kaidah, atau hak dan kewajiban yang mengikat mereka untuk ditaati dan dijalankan. Kesepakatan itu kemudian menimbulkan akibat hukum berupa hak dan kewajiban yang apabila kesepakatan itu dilanggar akan dikenakan sanksi. ${ }^{7}$

\footnotetext{
5 R. Subekti, Hukum Perjanjian, Jakarta: Intermasa, 1987, hlm. 1.

6 Abdulkadir Muhammad, Hukum Perikatan, Bandung: Citra Aditya Bakti, 1992, hlm. 78.

7 Sudikno Mertokusumo, Mengenal Hukum, Yogyakarta: Liberty, 1999, hlm. 81.
} 
Pada awal dimulainya suatu perjanjian, prinsip penting yang perlu diingat adalah prinsip kebebasan berkontrak di antara pihak yang berkedudukan seimbang dalam mencapai kesepakatan. Namun, berkaitan dengan aspek-aspek perekonomian yang semakin berkembang, saat ini para pihak mencari format yang lebih praktis. Salah satu pihak menyiapkan syarat-syarat yang sudah distandarkan pada suatu format perjanjian yang telah dicetak, berupa formulir untuk kemudian diberikan kepada pihak lainnya untuk disetujui (ditandatangani). Inilah yang dimaksudkan dengan perjanjian standar atau perjanjian baku. ${ }^{8}$

Perjanjian standar (standard contract, standardized contract, pad contract atau standard agreement) adalah suatu persetujuan yang dibuat para pihak mengenai sesuatu hal yang isinya telah ditentukan secara baku (standard). Perjanjian tersebut dituangkan secara tertulis serta menjadi tolok ukur atau patokan atau pedoman bagi konsumen yang mengadakan hubungan hukum dengan pengusaha. Perjanjian baku tersebut meliputi model, rumusan, dan ukuran. ${ }^{9}$ Menurut Sutan Remy Sjahdeini, istilah lain dari perjanjian baku adalah perjanjian adhesi, yang diartikannya sebagai perjanjian yang hampir seluruh klausul-klausulnya sudah dibakukan oleh pemakainya dan pihak lain pada dasarnya tidak mempunyai peluang untuk merundingkan atau meminta perubahan. Hanya beberapa hal saja yang belum dibakukan, misalnya yang menyangkut jenis, harga, jumlah, warna, tempat, waktu, dan beberapa hal lainnya yang spesifik dari obyek yang diperjanjikan. ${ }^{10}$

Perjanjian dengan syarat baku dilakukan oleh pelaku usaha antara lain dengan cara-cara: ${ }^{11}$

1. Memuatnya dalam butir-butir perjanjian yang konsepnya telah dipersiapkan terlebih dahulu oleh salah satu pihak biasanya oleh kalangan pengusaha, baik itu produsen, distributor atau pedagang eceran produk bersangkutan. Pokoknya disediakan oleh si penyedia barang dan/atau jasa yang ditawarkan pada orang banyak (perhatikan kontrak-kontrak jual beli atau beli sewa kendaraan bermotor, perumahan, alat-alat elektronik, dan lain-lain);

2. Dengan memuatnya dalam carik-carik kertas, baik berupa tabel, kwitansi, bon, tanda terima barang atau lain-lain bentuk penjualan dan/atau penyerahan barang (misalnya pada carik kertas/bon/tanda penyerahan barang dari toko,

8 N.H.T. Siahaan, Hukum Konsumen: Perlindungan Konsumen dan Tanggung Jawab Produk, Jakarta: Panta Rei, 2005, hlm. 105.

9 Abdulkadir Muhammad, Perjanjian Baku dalam Praktek Perusahaan Perdagangan, Bandung: Citra Aditya Bakti, 1992, hlm. 6.

10 Sutan Remy Sjahdeini, Kebebasan Berkontrak dan Perlindungan yang Seimbang Bagi Para Pihak dalam Perjanjian Kredit Bank di Indonesia, Jakarta: Institut Bankir Indonesia, 1993, hlm. 66.

11 Az Nasution, Hukum Perlindungan Konsumen: Suatu Pengantar, Cetakan Pertama, Jakarta: Daya Widya, 1999, hlm. 101-102. 
kedai, supermarket, dan sebagainya);

3. Dengan pembuatan pengumuman tentang berlakunya syarat-syarat baku di tempat-tempat tertentu, seperti di tempat-tempat parkir atau di hotel atau penginapan dengan meletakkan atau menempelkan pengumuman itu di meja atau ruang penerima tamu atau di ruang duduk kamar yang disewakan.

Ciri perjanjian baku menurut Mariam Darus Badrulzaman adalah: ${ }^{12}$

1. Isinya ditetapkan secara sepihak oleh pihak yang posisi (ekonominya) kuat;

2. Masyarakat (debitur) sama sekali tidak ikut bersama-sama menentukan isi perjanjian;

3. Terdorong oleh kebutuhannya debitur terpaksa menerima perjanjian itu;

4. Bentuk tertentu (tertulis);

5. Dipersiapkan secara massal dan kolektif.

Di Amerika Serikat, transaksi-transaksi tertentu yang dilakukan dengan perjanjian baku, tidak diperbolehkan memuat syarat berikut: ${ }^{13}$

1. Persetujuan pembeli untuk tidak menggugat pengusaha;

2. Pembebasan pembeli untuk menuntut penjual mengenai setiap perbuatan penagihan atau pemilikan kembali (barang yang dijual) yang dilakukan secara tidak sah;

3. Pemberian kuasa kepada penjual atau orang lain untuk menagih pembayaran atau pemilikan kembali barang tertentu;

4. Pembebasan penjual dari setiap tuntutan ganti kerugian pembeli terhadap penjual.

Implementasi dari perjanjian baku yang biasa digunakan banyak diterapkan dalam dunia bisnis dan perdagangan. Pada sektor jasa keuangan, perjanjian baku dimaksudkan untuk mempermudah operasional bisnis dan mengurangi ongkosongkos bisnis. Adapun yang merupakan contoh-contoh dari perjanjian baku yang sering dilakukan dalam praktik adalah sebagai berikut $:^{14}$

1. Kontrak (polis) asuransi;

2. Kontrak dibidang perbankan;

3. Kontrak sewa guna usaha;

4. Kontrak jual beli rumah atau apartemen dari perusahaan real estate;

5. Kontrak sewa menyewa gedung perkantoran;

6. Kontrak pembuatan credit card;

7. Kontrak pengiriman barang (darat, laut dan udara).

\footnotetext{
12 Salim H.S., Perkembangan Hukum Kontrak di Luar KUHPerdata, Jakarta: RajaGrafindo Persada, 2004, hlm. 22.

13 Stuart J. Faber, Handbook of Consumer Law, California : Lega Books, 1978, hIm. 55.

14 Munir Fuady, Hukum Kontrak (Buku Kedua), Bandung: Citra Aditya Bakti, 2007, hlm. 77.
} 
Dalam pelaksanaan perjanjian baku pihak konsumen hanya dihadapkan pada dua pilihan, yaitu: ${ }^{15}$

1. Jika konsumen membutuhkan barang atau jasa yang ditawarkan kepadanya, setujuilah perjanjian dengan syarat-syarat baku yang disodorkan oleh pengusaha (take it); atau

2. Jika konsumen tidak setuju dengan syarat-syarat yang ditawarkan itu, janganlah membuat perjanjian dengan pengusaha yang bersangkutan (leave it).

Karena konsumen hanya mempunyai dua pilihan menyetujui atau menolak, maka pada umumnya kontrak baku dibuat dan dipersiapkan oleh pihak yang secara ekonomi kedudukannya lebih baik atau kuat dari pihak lainnya. Pada hubungan antara nasabah dengan pihak bank pada umumnya kontraknya sudah dibuat secara standar oleh bank, sedangkan nasabah tinggal menandatanganinya. ${ }^{16}$ Akibatnya seseorang menjadi terpaksa melakukan perjanjian, misalnya karena dalam keadaan butuh sekali akan uang sehingga menandatangani perjanjian utang piutang dari rentenir dengan bunga tinggi, atau jika suatu perjanjian yang sudah dibuatkan konsepnya dan tinggal ditandatangani saja. Konsumen sendiri tidak mengerti isinya secara jelas, namun tetap disetujui karena yang dihadapi adalah lawan perikatannya yang memiliki posisi lebih tinggi, misalnya pengusaha besar, pejabat tinggi, dan sebagainya.

Bila pembatasan klausula baku tidak diatur secara jelas, maka PUJK akan lebih mendominasi dan akibatnya konsumen akan sangat dirugikan. PUJK akan membuat rumusan ketentuan-ketentuan internal yang bersifat klausula baku sebagai bagian dari perikatan kontraktual yang sifatnya menguntungkan dirinya atau sebaliknya amat merugikan konsumen. Dalam kesempatan itu pula konsumen karena berbagai alasan dan kondisi tertentu akan menerima atau menandatangani begitu saja perikatan yang mengandung klausula baku tersebut. Posisi konsumen yang relatif berada di bawah posisi produsen dimungkinkan untuk disalahgunakan dengan memanfaatkan keadaan (misbruik van omstandigheden). ${ }^{17}$

Menurut J. Satrio, hukum perjanjian dalam perkembangannya di Negeri Belanda menerima penyalahgunaan keadaan (misbruik van omstandigheden) sebagai unsur yang menyebabkan perjanjian yang ditutup dalam suasana seperti itu dapat dibatalkan, baik seluruhnya maupun sebagian daripadanya. ${ }^{18}$ Dalam peristiwa-peristiwa dimana penyalahgunaan keadaan menjadi permasalahan

\footnotetext{
15 Abdulkadir Muhammad, Op. cit., hlm. 9.

16 Yusuf Shofie, Perlindungan Konsumen dan Instrumen-instrumen Hukumnya, Bandung: Citra Aditya Bakti, 2000, hlm. 80.

17 Di Belanda dikenal suatu perbuatan yang melawan hukum yang disebut misbruik van omstandigheden, yakni penyalahgunaan keadaan. Perbuatan ini dijadikan sebagai alasan keempat dari cacat kehendak, setelah unsurunsur dwang (paksaan), dwaling (kekhilafan), dan bedrog (penipuan).

18 J. Satrio, Hukum Perjanjian, Bandung: Citra Aditya Bakti, 1992, hlm. 230.
} 
hukum di pengadilan, ada beberapa faktor yang dapat dianggap sebagai ciri penyalahgunaan keadaan, yaitu: ${ }^{19}$

1. Pada waktu menutup perjanjian, salah satu pihak ada dalam keadaan yang terjepit;

2. Karena keadaan ekonomis, kesulitan keuangan yang mendesak;

3. Karena hubungan antara atasan dengan bawahan, keunggulan ekonomis pada salah pihak, hubungan majikan dengan buruh, orang tua/wali dengan anak belum dewasa;

4. Karena keadaan, seperti pasien yang membutuhkan pertolongan dokter ahli;

5. Perjanjian tersebut mengandung hubungan yang timpang dalam kewajiban timbal-balik antara pihak (prestasi yang tak seimbang), pembebasan majikan dari risiko dan menggesernya menjadi tanggungan si buruh;

6. Kerugian yang sangat besar bagi salah satu pihak.

Uraian di atas jelas memperlihatkan bahwa posisi PUJK lebih kuat daripada konsumen, baik dari segi ekonomi, pengetahuan dan lain-lain. Hal tersebut mengakibatkan tidak adanya tawar-menawar yang seimbang antara produsen/penyalur produk (penjual) yang lazim disebut kreditur dan konsumen (debitur) dilain pihak. Dengan kedudukan atau posisi yang lebih tinggi dibanding konsumen, berpeluang besar untuk menyalahgunakan keadaan (misbruik van omstandigheden) dalam perjanjian baku.

\section{Peraturan Perlindungan Konsumen di Sektor Jasa Keuangan}

Hukum perlindungan konsumen dinilai mengalami kemajuan yang luar biasa pascalahirnya Peraturan Otoritas Jasa Keuangan Nomor 01/POJK.07/2013 tentang Perlindungan Konsumen Sektor Jasa Keuangan (untuk selanjutnya disingkat POJK Nomor 1/2013). Pernyataan tersebut disampaikan Inosentius Samsul, Pakar Hukum Perlindungan Konsumen Fakultas Hukum Universitas Indonesia, dimana peraturan tersebut memberikan sistem perlindungan konsumen yang spesifik, utamanya dalam bidang jasa keuangan. ${ }^{20}$

Spirit dari peraturan tersebut tidak diragukan lagi memperkuat sisi perlindungan konsumen. Ruang lingkup perlindungan konsumen dalam peraturan tersebut meliputi tiga hal pokok. Pertama, pengaturan hak konsumen atas informasi. Hal ini dibuat sebagai upaya mencegah kerugian konsumen sebelum transaksi. Ini menjadi sistem pengawasan preventif terhadap pelaku jasa keuangan. Kedua, berisi perlindungan hak atas fair agreement. Ketiga, berisi tentang

\footnotetext{
19 Ibid., hlm. 231-232.

${ }^{20}$ Inosentius Samsul, "Penegakan Hukum Perlindungan Konsumen Pasca Undang-Undang Otoritas Jasa Keuangan (OJK) dan Peraturan OJK Nomor 1 Tahun 2013", Seminar Hukum Kerja Sama Otoritas Jasa Keuangan (OJK) dan hukumonline.com, Jakarta, 21 November 2013.
} 
kompensasi dan kerugian konsumen. Secara keseluruhan, POJK Nomor 1/2013 sesuai dengan Undang-Undang Nomor 21 Tahun 2011 tentang OJK. Selain itu, peraturan ini juga selaras dengan UU PK, khususnya Pasal 19 UU PK tentang tanggung jawab pelaku usaha. Ruang lingkup yang terdapat dalam perlindungan konsumen tersebut sudah mencakupi kebutuhan konsumen, khususnya konsumen jasa keuangan.

POJK Nomor 1/2013 kemudian ditindaklanjuti dengan terbitnya 5 Surat Edaran OJK pada tahun 2014. Pertama, Surat Edaran OJK Nomor 1/SEOJK.07/2014 tentang Pelaksanaan Edukasi dalam Rangka Meningkatkan Literasi Keuangan Kepada Konsumen dan/atau Masyarakat (untuk selanjutnya disingkat SEOJK Nomor 1/2014), antara lain mengatur PUJK untuk memuat rencana edukasi ke dalam rencana bisnis tahunan dan kewajiban pelaporan pelaksanaannya kepada OJK. Penyusunan rencana edukasi harus mengacu kepada Strategi Nasional Literasi Keuangan yang telah diluncurkan oleh Presiden Republik Indonesia pada bulan November 2013 lalu. ${ }^{21}$

Kedua, Surat Edaran OJK Nomor 2/SEOJK.07/2014 tentang Pelayanan dan Penyelesaian Pengaduan Konsumen Pada Pelaku Usaha Jasa Keuangan (untuk selanjutnya disingkat SEOJK Nomor 2/2014), yang mengatur antara lain mengenai adanya fungsi atau unit yang menangani penyelesaian pengaduan konsumen oleh PUJK dan kewajiban memiliki sumber daya manusia, sistem dan prosedur penanganan pengaduan pada setiap PUJK. Selain itu, PUJK wajib menyampaikan laporan kepada OJK mengenai penyelesaian pengaduan secara berkala setiap tiga bulan. Ketiga, Surat Edaran OJK Nomor 12/SEOJK.07/2014 tentang Penyampaian Informasi Dalam Rangka Pemasaran Produk dan/atau Layanan Jasa Keuangan. Keempat, Surat Edaran OJK Nomor 13/SEOJK.07/2014 tentang Perjanjian Baku. Kelima, Surat Edaran OJK Nomor 14/SEOJK.07/2014 tentang Kerahasiaan dan Keamanan Data dan/atau Informasi Pribadi Konsumen.

Pada tanggal 23 Januari 2014 OJK kembali menerbitkan peraturan, yaitu Peraturan Otoritas Jasa Keuangan Nomor 1/POJK.07/2014 tentang Lembaga Alternatif Penyelesaian Sengketa di Sektor Jasa Keuangan (untuk selanjutnya disingkat POJK Nomor 1/2014). Tujuan pengaturan ini adalah untuk menciptakan mekanisme penyelesaian sengketa di sektor jasa keuangan yang cepat, murah, adil, dan efisien serta tersedianya mekanisme penyelesaian sengketa di sektor jasa keuangan yang bisa meningkatkan kepercayaan konsumen terhadap lembaga jasa keuangan.

\footnotetext{
${ }^{21}$ Sindonews.com, “OJK Terbitkan Aturan Perlindungan Konsumen”, http://ekbis.sindonews.com/read/ 839060/32/ojk-terbitkan-aturan-perlindungan-konsumen, diakses 24 Desember 2014.
} 


\section{Klausula Baku Menurut UUPK}

Pengaturan klausula baku dalam produk undang-undang untuk pertama kalinya diatur dalam UUPK, yang memberi batasan bahwa klausula baku adalah setiap aturan atau ketentuan dan syarat-syarat yang telah dipersiapkan dan diterapkan terlebih dahulu secara sepihak oleh pelaku usaha, yang dituangkan dalam suatu dokumen dan atau perjanjian yang mengikat dan wajib dipenuhi oleh konsumen. ${ }^{22}$ Penekanannya adalah pada prosedur pembuatan yang bersifat sepihak, bukan mengenai isinya. Padahal, pengertian 'klausula eksonerasi' tidak hanya mempersoalkan prosedur pembuatannya, melainkan juga isinya yang bersifat pengalihan kewajiban atau tanggung jawab pelaku usaha. ${ }^{23}$

Secara umum klausula baku yang dimuat dalam perjanjian baku tidak dilarang dan tetap berlaku bagi para pihak yang membuat transaksi. Larangan hanya pada pencantuman klausula baku yang disebut eksonerasi, yaitu klausula yang membebaskan, membatasi atau mengalihkan tanggung jawab pelaku usaha yang pada gilirannya akan memberatkan atau merugikan konsumen dari praktik pencantuman klausula baku tersebut. UUPK telah memberikan rambu-rambu perbuatan yang dilarang untuk mencantumkan klausula baku yang diatur dalam Pasal 18 ayat (1) UUPK.

Dalam ketentuan Pasal 18 ayat (1) UUPK menentukan bahwa pelaku usaha dalam menawarkan barang atau jasa yang ditujukan untuk diperdagangkan dilarang membuat atau mencantumkan klausula baku pada setiap dokumen dan atau perjanjiian dimana klausula tersebut akan mengakibatkan:

1. Pengalihan tanggung jawab pelaku usaha;

2. Menyatakan bahwa pelaku usaha berhak menolak penyerahan kembali barang yang dibeli konsumen;

3. Menyatakan bahwa pelaku usaha berhak menolak penyerahan kembali uang yang dibayarkan atas barang atau jasa yang dibeli konsumen;

4. Menyatakan pemberian kuasa dari konsumen kepada pelaku usaha, baik secara langsung maupun tidak langsung untuk melakukan segala tindakan sepihak yang berkaitan dengan barang yang dibeli oleh konsumen secara angsuran;

5. Mengatur perihal pembuktian atas hilangnya kegunaan barang atau jasa yang dibeli oleh konsumen;

6. Memberi hak kepada pelaku usaha untuk mengurangi manfaat jasa atau mengurangi harta kekayaan konsumen yang menjadi objek jual beli jasa;

7. Menyatakan tunduknya konsumen kepada peraturan yang berupa aturan baru, tambahan, lanjutan dan atau pengubahan lanjutan yang dibuat sepihak oleh pelaku usaha dalam masa konsumen memanfaatkan jasa yang dibelinya;

\footnotetext{
22 Pasal 1 angka 10 UU Nomor 8 Tahun 1999 tentang Perlindungan Konsumen.

${ }^{23}$ Shidarta, Hukum Perlindungan Konsumen Indonesia, Jakarta: Grasindo, 2000, hlm. 123.
} 
8. Menyatakan bahwa konsumen memberi kuasa kepada pelaku usaha untuk membebankan hak tanggungan, hak gadai atau hak jaminan terhadap barang yang dibeli oleh konsumen secara angsuran.

Selanjutnya Pasal 18 ayat (2) UU PK menentukan bahwa pelaku usaha dilarang mencantumkan klausula-klausula baku yang letak atau bentuknya sulit terlihat atau tidak dapat dibaca secara jelas atau yang pengungkapannya sulit dimengerti. Sebagai konsekuensi atas pelanggaran terhadap ketentuan Pasal 18 ayat (1) dan (2) tersebut dalam Pasal 18 ayat (3) UU PK dinyatakan 'batal demi hukum' atas setiap klausula baku yang telah ditetapkan pelaku usaha pada dokumen atau perjanjian yang memuat ketentuan yang dilarang Pasal 18 ayat (1) maupun Pasal 18 ayat (2) tersebut.

Pelaku usaha yang mencantumkan klausula baku dengan letak atau bentuk seperti diuraikan di atas dalam dokumen atau perjanjian baku yang dibuatnya dikenakan sanksi sebagai berikut:

\section{Sanksi Perdata}

a. Perjanjian standar yang dibuat oleh pelaku usaha jika digugat di depan pengadilan oleh konsumen, akan menyebabkan hakim harus membuat putusan bahwa perjanjian baku tersebut batal demi hukum;

b. Pelaku usaha yang pada saat ini telah mencantumkan klausula baku dalam dokumen atau perjanjian baku yang digunakannya wajib merevisinya agar sesuai dengan UU PK;

c. Konsumen yang dirugikan akibat pencantuman klausula baku dapat menuntut ganti rugi secara perdata.

\section{Sanksi Pidana}

Pelaku usaha yang melanggar ketentuan sebagaimana dimaksud dalam Pasal 18, menurut Pasal 62 ayat (1) UU PK dipidana dengan pidana penjara paling lama 5 (lima) tahun atau pidana denda paling banyak Rp2.000.000.000,00 (dua miliar rupiah).

Selanjutnya beberapa hukuman tambahan menurut Pasal 63 UU PK, dapat berupa:

1. Perampasan barang tertentu;

2. Pengumuman keputusan hakim;

3. Pembayaran ganti rugi;

4. Perintah penghentian kegiatan tertentu yang menyebabkan timbulnya kerugian konsumen;

5. Kewajiban penarikan barang dari peredaran; atau

6. Pencabutan izin usaha.

Dengan demikian setiap pelaku tindak pidana tertentu yang disebutkan dalam Pasal 62 UUPK dapat pula dijatuhkan hukuman tambahan sebagaimana diatur 
dalam Pasal 63 UUPK tersebut. Ketentuaan di atas belum mengatur mengenai penyalahgunaan keadaan. Perlindungan hukum bagi konsumen dalam perjanjian baku selain dengan menggunakan instrumen hukum sebagaimana dijelaskan di atas, dapat juga menggunakan instrumen lain yaitu dengan menerapkan ajaran penyalahgunaan keadaan (misbruik van omstandigheden).

\section{E. Klausula Baku Menurut SEOJK Nomor 13/SEOJK.07/2014}

SEOJK Nomor 13/SEOJK.07/2014 tentang Perjanjian Baku merupakan peraturan pelaksana dari Peraturan OJK Nomor 1/POJK.07/2013 tentang Perlindungan Konsumen Sektor Jasa Keuangan, yang mulai diberlakukan tanggal 20 Agustus 2014. Pada prinsipnya ketentuan mengenai larangan pencantuman perjanjian baku yang merugikan konsumen yang terdapat dalam SEOJK Nomor 13/SEOJK.07/2014 sama dengan ketentuan yang terdapat dalam Pasal 18 ayat (1) UU PK di atas. Perjanjian baku menurut SEOJK Nomor 13/SEOJK.07/2014 adalah perjanjian tertulis yang ditetapkan secara sepihak oleh PUJK dan memuat klausula baku tentang isi, bentuk, maupun cara pembuatan, dan digunakan untuk produk dan/atau layanan kepada konsumen secara massal. ${ }^{24}$

Menurut SEOJK Nomor 13/SEOJK.07/2014, ketentuan klausula dalam perjanjian baku adalah sebagai berikut :

1. PUJK wajib memenuhi keseimbangan, keadilan, dan kewajaran dalam pembuatan perjanjian dengan konsumen;

2. Dalam hal PUJK merancang, merumuskan, menetapkan, dan menawarkan perjanjian baku, PUJK wajib mendasarkan pada ketentuan sebagaimana dimaksud pada angka 1;

3. Klausula dalam perjanjian baku yang dilarang adalah yang memuat:

a. Klausula eksonerasi/eksemsi, yaitu yang isinya menambah hak dan/atau mengurangi kewajiban PUJK, atau mengurangi hak dan/atau menambah kewajiban konsumen;

b. Penyalahgunaan keadaan, yaitu klausula suatu kondisi dalam perjanjian baku yang memiliki indikasi penyalahgunaan keadaan. Contoh terhadap kondisi ini misalkan memanfaatkan alasan konsumen yang mendesak karena kondisi tertentu atau dalam keadaan darurat dan secara sengaja atau tidak sengaja PUJK tidak menjelaskan manfaat, biaya, dan risiko dari produk dan/atau dari layanan yang dibeli;

c. Menyatakan pemberian kuasa dari konsumen kepada PUJK baik secara langsung maupun tidak langsung, untuk melakukan segala tindakan sepihak atas barang yang diagunkan oleh konsumen, kecuali tindakan sepihak tersebut dilakukan berdasarkan peraturan perundang-undangan;

\footnotetext{
${ }^{24}$ Surat Edaran Otoritas Jasa Keuangan, SEOJK Nomor 13/SEOJK.07/2014 tentang Perjanjian Baku.
} 
d. Mewajibkan konsumen untuk membuktikan dalil PUJK yang menyatakan bahwa hilangnya kegunaan produk dan/atau layanan yang dibeli oleh konsumen bukan merupakan tanggung jawab PUJK;

e. Memberi hak kepada PUJK untuk mengurangi kegunaan produk dan/atau layanan atau mengurangi harta kekayaan konsumen yang menjadi objek perjanjian produk dan layanan;

f. Menyatakan bahwa konsumen tunduk pada peraturan baru, tambahan, lanjutan dan/atau perubahan yang dibuat secara sepihak oleh PUJK dalam masa konsumen memanfaatkan produk dan/atau layanan yang dibelinya; dan/atau

g. Menyatakan bahwa konsumen memberi kuasa kepada PUJK untuk pembebanan hak tanggungan, hak gadai, atau hak jaminan atas produk dan/atau layanan yang dibeli oleh konsumen secara angsuran.

Format perjanjian baku yang terdapat dalam SEOJK Nomor 13/SEOJK.07/2014 adalah sebagai berikut:

1. Perjanjian baku yang memuat hak dan kewajiban konsumen dan persyaratan yang mengikat konsumen secara hukum, wajib menggunakan huruf, tulisan, simbol, diagram, tanda, istilah, frasa yang dapat dibaca dan/atau kalimat yang sederhana dalam Bahasa Indonesia yang mudah dimengerti oleh konsumen;

2. Apabila konsumen menemukan ketidakjelasan, PUJK wajib memberikan penjelasan atas istilah frasa, kalimat dan/atau simbol, diagram, dan tanda yang belum dipahami oleh konsumen, baik secara tertulis di dalam perjanjian baku, maupun secara lisan sebelum perjanjian baku ditandatangani;

3. Dalam perjanjian baku menggunakan istilah, frasa, dan/atau kalimat dari bahasa lain selain Bahasa Indonesia, maka istilah, frasa, dan/atau kalimat dari bahasa lain tersebut harus disandingkan dengan istilah, frasa, dan/atau kalimat dalam Bahasa Indonesia;

4. Dalam perjanjian baku wajib memuat pernyataan sebagai berikut: "PERJANJIAN INI TELAH DISESUAIKAN DENGAN KETENTUAN PERATURAN PERUNDANG-UNDANGAN TERMASUK KETENTUAN PERATURAN OTORITAS JASA KEUANGAN";

5. Selain berbentuk cetak, perjanjian baku dapat berbentuk digital atau elektronik atau disebut e-contract untuk ditawarkan oleh PUJK melalui media elektronik;

6. Dalam hal perjanjian baku berbentuk cetak, maka berlaku hal-hal sebagai berikut:

a. PUJK wajib memastikan terdapat persetujuan tertulis konsumen dengan cara antara lain membubuhkan tanda tangan dalam perjanjian baku atau dokumen lain yang merupakan bagian tidak terpisahkan dari perjanjian baku yang menyatakan persetujuan konsumen; 
b. PUJK dapat menggandakannya sehingga transaksi dapat memenuhi tujuan, yaitu cepat, efektif, efisien, berulang, dan memberikan kepastian hukum;

c. PUJK memberikan waktu yang cukup kepada konsumen untuk membaca dan memahami perjanjian baku sebelum menandatanganinya atau sebelum efektif berlakunya perjanjian baku;

d. PUJK wajib mematuhi ketentuan dalam peraturan perundang-undangan yang berlaku, antara lain undang-undang yang mengatur mengenai informasi dan transaksi elektronik.

\section{F. Penerapan Perjanjian Baku Dalam Transaksi Bisnis Sektor Jasa Keuangan}

Setiap saat konsumen dapat dengan mudah menemukan iklan layanan sektor jasa keuangan di media massa cetak maupun elektronik, media iklan luar ruang (outdoor), media penyiaran, maupun melalui berbagai leaflet, pamflet, brosur, dan lain-lain. Iklan ini diperlihatkan langsung di rumah maupun di tempat-tempat strategis lainnya, seolah tidak ada ruang yang terlewat bagi mereka untuk melakukan promosi. Promosi jelas bukan aktivitas yang illegal (melawan hukum), namun promosi yang menyesatkan, mengelabuhi, ataupun yang berisi informasi yang salah (tidak benar) jelas melawan hukum dan merugikan konsumen. Tahap inilah yang menjadi awal dari lemahnya konsumen, yaitu tidak tersedianya informasi yang benar, jelas dan jujur, yang memungkinkan konsumen untuk menjatuhkan pilihan dengan tepat dan benar. Promosi yang gencar seolah tidak akan pernah berhenti, sehingga sering menyesatkan dan mengelabuhi konsumen.

Manakala konsumen tertarik dengan promosi yang ditawarkan sesungguhnya ia tidak menyadari persoalan yang akan dihadapinya. Melalui ketertarikan tersebut, konsumen dihadapkan pada formula perjanjian baku yang didalamnya sarat dengan klausula baku, dimana konsumen dapat menyetujuinya atau tidak. Klausula baku tersebut perlu untuk ditinjau ulang keberadaannya, karena dengan adanya klausula baku tersebut terlihat sangat jelas kedudukan konsumen yang berada selangkah dibelakang para pelaku usaha jasa keuangan. Praktis tidak ada jasa keuangan yang tidak menggunakan format perjanjian baku dan klausula baku dalam bertransaksi dengan konsumennya saat ini. Bentuk perjanjian semacam ini jelas memposisikan konsumen sebagai pihak yang tidak punya daya tawar dan apapun mengenai isi dari perjanjian baku, sehingga mau tidak mau terpaksa disetujui, bahkan meskipun konsumen mengetahui pada saat itu bahwa isinya memberatkan dirinya.

Dalam wacana perlindungan konsumen, hal ini dikenal sebagai prinsip take it or leave it. Prinsip ini menunjuk pada suatu keadaan yang memposisikan ketiadaan daya tawar konsumen di depan pelaku usaha. Hal tersebutlah yang penulis kurang setujui, seharusnya antara pelaku usaha khususnya sektor jasa keuangan memiliki posisi yang saling menguntungkan dengan itikad baik. Keuntungan memang 
diperlukan akan tetapi kepercayaan, integritas, dan tanggung jawab adalah tidak dapat dilupakan. Karena suatu usaha yang dilandasi dengan ketidakadilan hanya akan membuat kerugian yang nyata dan keuntungan yang sementara.

Klausula baku yang merupakan suatu bentuk perjanjian memang secara teoretis masih mengundang perdebatan, khususnya dalam kaitannya dengan asas kebebasan berkontrak (freedom of contract) dan syarat-syarat perjanjian. Dalam perjanjian baku, kebebasan dan pemberian kesepakatan untuk melakukan kontrak tidak dilakukan sebebas dengan perjanjian secara langsung, dengan melibatkan para pihak untuk menegosiasikan klausula perjanjian. ${ }^{25}$

Kendatipun demikian, harus pula diakui bahwa perjanjian baku sangat dibutuhkan dalam dunia perdagangan yang semakin pesat dewasa ini. Dengan penggunaan klausula baku tersebut, berarti para pihak dapat mempersingkat waktu bernegosiasi. Di samping itu, perjanjian baku juga tetap mengikat para pihak dan pada umumnya beban tanggung jawab para pihak adalah berat sebelah. Langkah yang harus dilakukan bukan melarang atau membatasi penggunaan klausula baku, melainkan melarang atau membatasi penggunaan klausula-klausula tertentu dalam perjanjian baku tersebut. ${ }^{26}$

Berikut ini diberikan contoh beberapa klausula baku yang dilarang dan merugikan konsumen di sektor jasa keuangan, yaitu:

1. Menyatakan pengalihan tanggung jawab atau kewajiban PUJK kepada konsumen. Contoh dalam perjanjian penerbitan kartu kredit dinyatakan bahwa:

"Pemegang kartu membebaskan penerbit kartu kredit dari tanggung jawab dan pemberian ganti rugi dalam bentuk apapun yang mungkin timbul dari dari keluhan, atau gugatan yang diajukan oleh pemegang kartu atau kuasanya." Klausula baku ini mengalihkan tanggung jawab yang secara hukum merupakan tanggung jawab pelaku usaha, dibebankan kepada konsumen melalui perjanjian;

2. Menyatakan bahwa PUJK berhak menolak pengembalian uang yang telah dibayar oleh konsumen atas produk dan/atau layanan yang dibeli Konsumen tidak dapat membatalkan pembelian produk dan/atau layanan dan meminta penyerahan uangnya karena produk dan/atau layanannya tidak sesuai dengan perjanjian. Contoh klausula baku pada perjanjian pengikatan jual beli rumah, yang menyatakan bahwa: "booking feeberlaku 7 hari dan apabila lewat 7 hari tidak melakukan pembayaran dianggap sudah mengundurkan diri dan developer berhak menjual kembali barang tersebut";

3. Menyatakan pemberian kuasa dari konsumen kepada PUJK, baik secara

\footnotetext{
25 Zulham, Hukum Perlindungan Konsumen, Jakarta: Kencana Prenada Media Group, 2013, hlm. 76.

26 Jerry J. Philips, Product Liability, St. Paul, Minnesota: West Publishing Company, 1993, hlm. 130.
} 
langsung maupun tidak langsung, untuk melakukan segala tindakan sepihak atas barang yang diagunkan oleh konsumen, kecuali tindakan sepihak tersebut dilakukan berdasarkan peraturan perundang-undangan. Ketentuan ini menegaskan bahwa PUJK dapat melakukan tindakan sepihak atas benda yang diagunkan oleh konsumen, jika antara konsumen dan PUJK terikat perjanjian tersendiri yang bersifat accessoir terhadap perikatan pokok tentang pembelian produk dan/atau layanan jasa keuangan. Contoh: Jika dalam pembiayaan kendaraan bermotor yang dibebani dengan jaminan fidusia, PUJK dapat melakukan eksekusi terhadap benda yang menjadi objek jaminan fidusia, tanpa persetujuan dari konsumen pembiayaan, karena jaminan fidusia dilakukan berdasarkan Undang-Undang tentang Jaminan Fidusia;

4. Mengatur tentang kewajiban pembuktian oleh konsumen, jika PUJK menyatakan bahwa hilangnya kegunaan produk dan/atau layanan yang dibeli oleh konsumen, bukan merupakan tanggung jawab PUJK. Contoh dari klausula baku yang dilarang adalah: "Dalam suatu tuntutan, gugatan atau perkara lainnya di mana PUJK menyatakan bahwa suatu kerusakan atau kerugian secara langsung maupun tidak langsung disebabkan oleh satu atau lebih risikorisiko yang dikecualikan diatur dalam ketentuan ini, maka merupakan kewajiban konsumen untuk membuktikan sebaliknya." Klausula baku semacam ini bertentangan dengan asas hukum pembuktian yang menyatakan bahwa siapa yang mendalilkan harus membuktikan;

5. Memberi hak kepada PUJK untuk mengurangi kegunaan produk dan/atau layanan atau mengurangi harta kekayaan konsumen yang menjadi objek perjanjian produk dan layanan;

6. Menyatakan bahwa konsumen tunduk pada peraturan baru, tambahan, lanjutan dan/atau perubahan yang dibuat secara sepihak oleh PUJK dalam masa konsumen memanfaatkan produk dan/atau layanan yang dibelinya. Contohnya dalam perjanjian pembukaan rekening baru di PUJK, yang menyatakan: "Tunduk pada syarat dan ketentuan yang berlaku pada PUJK beserta segala perubahan menjadi satu kesatuan yang tidak terpisahkan dari formulir aplikasi rekening ini." Berdasarkan asas kepatutan, para pihak terikat pada syarat-syarat perjanjian yang seharusnya sudah diketahui sebelumnya. Para pihak tidak mungkin dapat mengetahui dan memahami syarat-syarat yang belumada;

7. Menyatakan bahwa konsumen memberi kuasa kepada PUJK untuk pembebanan hak tanggungan, hak gadai, atau hak jaminan atas produk dan/atau layanan yang dibeli oleh konsumen secara angsuran PUJK apabila melakukan pembebanan hak tanggungan, hak gadai atau hak jaminan atas produk dan/atau layanan yang dibeli konsumen secara angsuran, harus 
menggunakan surat kuasa terpisah dengan perjanjian pokoknya.

Sejatinya masalah penggunaan klausula baku dalam perjanjian baku sudah dibatasi penggunaannya oleh Pasal 18 UU PK, namun sebagaimana sudah diketahui, efektivitas ketentuan ini masih jauh dari harapan. Penggunaan perjanjian baku dengan klausula baku yang memberatkan dan merugikan konsumen (dan melanggar Pasal 18 UU PK) masih dengan mudah ditemukan di berbagai praktik layanan jasa keuangan maupun jasa-jasa di sektor lain. Ketiadaan lembaga dan otoritas pemerintah yang berwenang menjadi pengawas dan memastikan berlakunya Pasal 18 UU PK tersebut, mengakibatkan standard term contract menjadi senjata yang ampuh bagi pelaku usaha untuk memproteksi kepentingannya di hadapan konsumen. Inilah salah satu kelemahan mendasar UU PK karena meskipun mandat pengawasan penggunaan standard term contract itu secara normatif diberikan kepada BPSK. Namun sejak lahirnya BPSK, praktis mandat itu tidak bisa dijalankan karena ketiadaan aturan pelaksanaannya, maupun juga karena mandat ini memang tidak tepat diberikan kepada lembaga penyelesaian sengketa seperti BPSK. Oleh karena itu, kedepannya masalah penggunaan klausula baku dalam perjanjian baku ini semestinya diatur dengan jelas dan diawasi penggunaannya sehingga tidak mendistorsi makna hubungan kontraktual antara konsumen dengan penyedia jasa.

PUJK sebagai suatu perusahaan harus dapat menerapkan prinsip tata kelola perusahaan yang baik (good corporate governance) pada setiap aspek bisnis dan tata kelola perusahaan. Salah satu asas good corporate governance adalah kesetaraan dan kewajaran (fairness). Berdasarkan asas tersebut, PUJK harus senantiasa memperhatikan kepentingan konsumen selaku pemangku kepentingan (stakeholder) berdasarkan asas kesetaraan dan kewajaran, misalnya tidak mencantumkan klausula baku yang merugikan konsumen dalam perjanjian bakunya.

Apabila dihubungkan dengan Teori Keadilan dari John Rawls, ditegaskan bahwa program penegakan keadilan yang berdimensi kerakyatan haruslah memerhatikan dua prinsip keadilan, yaitu memberi hak dan kesempatan yang sama atas kebebasan dasar yang paling luas seluas kebebasan yang sama bagi setiap orang, serta mampu mengatur kembali kesenjangan sosial ekonomi yang terjadi sehingga dapat memberi keuntungan yang bersifat timbal balik (reciprocal benefits) bagi setiap orang, baik mereka yang berasal dari kelompok beruntung maupun tidak beruntung. ${ }^{27}$ Seharusnya PUJK dapat memberikan hak dan kesempatan yang sama kepada konsumen dalam merumuskan klausula dalam perjanjian bakunya. Dengan

\footnotetext{
27 Salim H.S. dan Erlies Septiana Nurbani, Penerapan Teori Hukum pada Penelitian Disertasi dan Tesis, Buku Kedua, Jakarta: RajaGrafindo Persada, 2014, hlm. 31.
} 
demikian diharapkan akan tercipta hubungan timbal balik yang saling menguntungkan, dimana konsumen menjadi cerdas dan mandiri yang mengetahui akan hak dan kewajibannya, serta PUJK menjadi pelaku usaha yang bertanggung jawab.

Kemudian apabila mengacu pendapat Friedman, ${ }^{28}$ disebutkan bahwa sistem hukum terdiri dari tiga elemen, yaitu elemen struktur hukum (legal structure), substansi hukum (legal substance) dan budaya hukum (legal culture). Berdasarkan pendapat tersebut, dapat disimpulkan bahwa pengadilan, DPR, Badan Perlindungan Konsumen Nasional (BPKN), BPSK, Lembaga Perlindungan Konsumen Swadaya Masyarakat (LPKSM), dan OJK merupakan aspek struktur dari sistem hukum perlindungan konsumen.

Elemen kedua dari sistem hukum adalah substansi hukum. Friedman mengatakan bahwa, yang dimaksud dengan substansi hukum adalah peraturanperaturan yang ada, norma-norma dan aturan tentang perilaku manusia atau yang biasanya dikenal orang sebagai 'hukum'. Misalnya, dalam konteks perlindungan konsumen ketentuan tentang larangan pencantuman klausula baku yang merugikan konsumen, ketentuan tentang hak dan kewajiban antara konsumen dan PUJK.

Sedangkan mengenai budaya hukum, Friedman mengartikannya sebagai sikap dari masyarakat terhadap hukum dan sistem hukum yang meliputi keyakinan, nilai, gagasan, serta harapan masyarakat tentang hukum. Hal tersebut biasanya ditunjukkan melalui kepatuhan hukum para pemangku kepentingan terhadap UU PK sebagai payung hukum dan peraturan perundang-undangan dibidang perlindungan konsumen lainnya; sikap konsumen cerdas dan mandiri yang mengetahui akan hak dan kewajibannnya; serta PUJK yang bertanggung jawab terhadap produk yang ditawarkannya.

Terpenuhinya ketiga elemen di atas, seharusnya sudah cukup untuk melindungi kepentingan para konsumen dari perbuatan PUJK yang merugikan konsumen.

\section{G. Penutup}

Berdasarkan uraian dan pembahasan di atas, maka dapat disimpulkan hal-hal sebagai berikut:

1. UUPK telah memberikan rambu-rambu perbuatan yang dilarang untuk mencantumkan klausula baku yang diatur dalam Pasal 18 ayat (1) UUPK, dan Pasal 18 ayat (2) UUPK yang menentukan bahwa pelaku usaha dilarang mencantumkan klausula-klausula baku yang letak atau bentuknya sulit terlihat atau tidak dapat dibaca secara jelas atau yang pengungkapannya sulit

\footnotetext{
${ }^{28}$ W. Friedman, Legal Theory, London: Steven \& Sons Limited, 1990, hlm. 22.
} 
dimengerti. Sebagai konsekuensi atas pelanggaran terhadap ketentuan Pasal 18 ayat (1) dan (2) tersebut dalam Pasal 18 ayat (3) UU PK menyatakan batal demi hukum setiap klausula baku yang telah ditetapkan pelaku usaha pada dokumen atau perjanjian yang memuat ketentuan yang dilarang Pasal 18 ayat (1) maupun perjanjian baku yang memiliki ketentuan yang dilarang Pasal 18 ayat (2);

2. PUJK yang mencantumkan klausula baku dalam dokumen atau perjanjian baku yang dibuatnya jika di kemudian hari merugikan konsumen, maka PUJK tersebut dapat dikenakan sanksi perdata dan sanksi pidana serta dapat pula dijatuhkan hukuman tambahan sebagaimana diatur dalam Pasal 63 UU PK, dan instrumen hukum lainnya, yaitu dengan jalan penerapan ajaran penyalahgunaan keadaan (misbruik van omstandigheden) yang diatur dalam SEOJK Nomor 13/SEOJK.07/2014;

3. Dalam perjanjian baku yang dibuat oleh PUJK tetap harus mengikuti ketentuan Pasal 1320 KUHPerdata jo Pasal 1338 KUHPerdata, bahwa kemudian pihak konsumen diberi waktu untuk mempelajari isi perjanjian baku tersebut, jika pihak konsumen merasa bisa mengikuti isi perjanjian tersebut dan jika ada perubahan yang dikehendaki lalu disepakati dan/atau tidak jadi, maka semua kembali kepada para pihak yang dalam posisi take it or leave it. Jikapun dalam posisi take it dan terjadi masalah di kemudian hari yang dapat dibuktikan kesalahan dari pihak PUJK, maka PUJK tersebut dapat dikenakan sanksi sebagaimana diatur dalam Pasal 62 dan Pasal 63 UU PK, serta Pasal 53 POJK Nomor 1/2013;

4. Dari sisi PUJK bahwa implementasi perjanjian standar yang dibuat oleh PUJK dimaksudkan untuk mencari kepraktisan dan efisiensi, sehingga mempermudah operasional bisnis dan mengurangi ongkos-ongkos bisnis. Kemudian pemberlakuan SEOJK Nomor 13/SEOJK.07/2014 sebagai peraturan pelaksana dari POJK Nomor 1/2013 harus juga memperhatikan ketentuan UU Nomor 4 Tahun 1996 tentang Hak Tanggungan dan UU Nomor 42 Tahun 1999 tentang Jaminan Fidusia, yang memberikan perlindungan hukum kepada PUJK jika debitur atau konsumen cidera janji (wanprestasi);

5. Dalam era perlindungan konsumen, pengaturan isi perjanjian standar yang memuat klausula baku tidak lagi mutlak berada di tangan pelaku usaha, melainkan sudah memerlukan pengawasan secara efektif, baik dari masyarakat/konsumen, LPKSM, pemerintah, BPSK maupun OJK. Terutama BPSK yang mempunyai tugas melakukan pengawasan terhadap pencantuman klausula baku, dan OJK yang mempunyai fungsi melakukan pengawasan terhadap kegiatan PUJK; 
6. Dengan bersinerginya 3 elemen hukum (legal structure, legal substance dan legal culture), diharapkan efektivitas sistem hukum perlindungan konsumen sektor jasa keuangan di Indonesia dapat dilaksanakan dengan sebaik-baiknya. Setidaknya ada harapan baru bagi konsumen untuk mendapatkan perlindungan hukum dalam melakukan transaksi bisnis sektor jasa keuangan, seperti dalam SEOJK Nomor 13/SEOJK.07/2014 secara tegas PJUK dilarang mencantumkan klausula baku dalam perjanjian standarnya yang merugikan konsumen.

\section{Daftar Pustaka \\ Daftar Buku}

Abdul Halim Barkatulah, Hukum Perlindungan Konsumen: Kajian Teoretis dan Perkembangan Pemikiran, Nusa Media, Bandung, 2008.

Abdulkadir Muhammad, Hukum Perikatan, Citra Aditya Bakti, Bandung, 1992. , Perjanjian Baku dalam Praktek Perusahaan Perdagangan,

Citra Aditya Bakti, Bandung, 1992.

Az Nasution, Hukum Perlindungan Konsumen: Suatu Pengantar, Cetakan Pertama, Daya Widya, Jakarta, 1999.

Friedman, W., Legal Theory, Steven \& Sons Limited, London, 1990.

Inosentius Samsul, Perlindungan Konsumen: Kemungkinan Penerapan Tanggung Jawab Mutlak, Pascasarjana FHUI, Jakarta, 2004.

J. Satrio, Hukum Perjanjian, Citra Aditya Bakti, Bandung, 1992.

Jerry J. Philips, Product Liability, West Publishing Company, St. Paul, Minnesota, 1993.

Munir Fuady, Hukum Kontrak (Buku Kedua), Citra Aditya Bakti, Bandung, 2007.

N.H.T. Siahaan, Hukum Konsumen: Perlindungan Konsumen dan Tanggung Jawab Produk, Panta Rei, Jakarta, 2005.

R. Subekti, Hukum Perjanjian, Intermasa, Jakarta, 1987. ,Hukum Perikatan, Citra Aditya Bakti, Bandung, 1992.

Salim H.S., Perkembangan Hukum Kontrak di Luar KUHPerdata, RajaGrafindo Persada, Jakarta, 2004.

Salim H.S. dan Erlies Septiana Nurbani, Penerapan Teori Hukum Pada Penelitian Disertasi dan Tesis, Buku Kedua, RajaGrafindo Persada, Jakarta, 2014.

Shidarta, Hukum Perlindungan Konsumen Indonesia, Grasindo, Jakarta, 2000.

Stuart J. Faber, Handbook of Consumer Law, Lega Books, California, 1978.

Sudikno Mertokusumo, Mengenal Hukum, Liberty, Yogyakarta, 1999.

Sutan Remy Sjahdeini, Kebebasan Berkontrak dan Perlindungan yang Seimbang Bagi Para Pihak dalam Perjanjian Kredit Bank di Indonesia. Institut Bankir Indonesia, Jakarta, 1993. 
Yusuf Shofie, Perlindungan Konsumen dan Instrumen-instrumen Hukumnya, Citra Aditya Bakti, Bandung, 2000.

Yusuf Shofie dan Somi Awan, Sosok Peradilan Konsumen: Mengungkap Pelbagai Persoalan Mendasar BPSK, Piramedia, Jakarta, 2004.

Zulham, Hukum Perlindungan Konsumen, Kencana Prenada Media Group, Jakarta, 2013.

\section{Dokumen Hukum}

Undang-Undang tentang Perlindungan Konsumen. UU Nomor 8 Tahun 1999.LN No. 42 Tahun 1999. TLN No. 3821.

Undang-Undang tentang Otoritas Jasa Keuangan. UU Nomor 21 Tahun 2011. LN No. 111 Tahun 2011. TLN No. 5253.

Peraturan Otoritas Jasa Keuangan tentang Perlindungan Konsumen Sektor Jasa Keuangan. POJK Nomor 1/POJK.07/2013.

Peraturan Otoritas Jasa Keuangan tentang Lembaga Alternatif Penyelesaian Sengketa (LAPS) di Sektor Jasa Keuangan. POJK Nomor 1/POJK.07/2014.

Surat Edaran Otoritas Jasa Keuangan tentang Pelaksanaan Edukasi Dalam Rangka Meningkatkan Literasi Keuangan Kepada Konsumen dan/atau Masyarakat. SEOJK Nomor 1/SEOJK.07/2014.

Surat Edaran Otoritas Jasa Keuangan tentang Pelayanan dan Penyelesaian Pengaduan Konsumen pada Pelaku Usaha Jasa Keuangan. SEOJK Nomor 2/SEOJK.07/2014.

Surat Edaran Otoritas Jasa Keuangan tentang Penyampaian Informasi Dalam Rangka Pemasaran Produk dan/atau Layanan Jasa Keuangan. SEOJK Nomor 12/SEOJK.07/2014.

Surat Edaran Otoritas Jasa Keuangan tentang Perjanjian Baku. SEOJK Nomor 13/SEOJK.07/2014.

Surat Edaran Otoritas Jasa Keuangan tentang Kerahasiaan dan Keamanan Data dan/atau Informasi Pribadi Konsumen. SEOJK Nomor 14/SEOJK.07/2014.

\section{Dokumen Lain}

Harian Seputar Indonesia, "OJK Terbitkan Aturan Perlindungan Konsumen", http://ekbis.sindonews.com/read/839060/32/ojk-terbitkan-aturanperlindungan-konsumen, diakses 24 Desember 2014.

Inosentius Samsul, "Penegakan Hukum Perlindungan Konsumen Pasca UndangUndang Otoritas Jasa Keuangan (OJK) dan Peraturan OJK Nomor 1 Tahun 2013", Seminar diselenggarakan oleh Otoritas Jasa Keuangan bekerjasama dengan hukumonline.com, di Kridangga Ballroom, Atlet Century Park Hotel Jakarta, 21 November 2013. 